\title{
High Performance Zero-Bleed CLSM/Grout Mixes for High-Level Waste Tank Closures Strategic Research and Development - FY99 Report
}

by

C. A. Langton

Westinghouse Savannah River Company

Savannah River Site

Aiken, South Carolina 29808

N. Rajendran

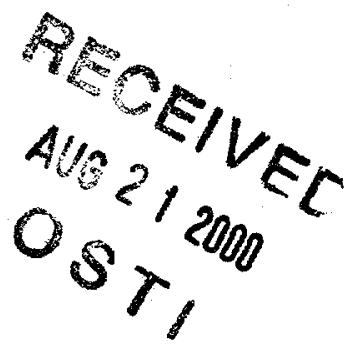

Consultant

GA USA

This paper was prepared in connection with work done under the above contract number with the U.S. Department of Energy. By acceptance of this paper, the publisher and/or recipient acknowledges the U. S. Government's right to retain a nonexclusive, royalty-free license in and to any copyright covering this paper, along with the right to reproduce and to authorize others to reproduce all or part of the copyrighted paper. 


\section{DISCLAIMER}

This report was prepared as an account of work sponsored by an agency of the United States Government. Neither the United States Government nor any agency thereof, nor any of their employees, makes any warranty, express or implied, or assumes any legal liability or responsibility for the accuracy, completeness, or usefulness of any information, apparatus, product or process disclosed, or represents that its use would not infringe privately owned rights. Reference herein to any specific commercial product, process or service by trade name, trademark, manufacturer, or otherwise does not necessarily constitute or imply its endorsement, recommendation, or favoring by the United States Government or any agency thereof. The views and opinions of authors expressed herein do not necessarily state or reflect those of the United States Government or any agency thereof.

This report has been reproduced directly from the best available copy.

Available for sale to the public, in paper, from: U.S. Department of Commerce, National Technical Information Service, 5285 Port Royal Road, Springfield, VA 22161, phone: (800) 553-6847, fax: (703) 605-6900 email: orders@ntis.fedworld.gov online ordering: http://www.ntis.gov/ordering.htm

Available electronically at http://www.doe.gov/bridge Available for a processing fee to U.S. Department of Energy and its contractors, in paper, from: U.S. Department of Energy, Office of Scientific and Technical Information, P.O. Box 62, Oak Ridge, TN 37831-0062, phone: (865)576-8401, fax: (865) $576-5728$

email: reportseadonis.osti.gov 


\section{DISCLAIMER}

Portions of this document may be illegible in electronic image products. Images are produced from the best available original document. 
Key Words: Waste Tank Closure

Controlled Low Strength Materials

High-Level Waste Treatment

High-Level Waste Tank Closure

Retention: Permanent

\title{
HIGH PERFORMANCE ZERO-BLEED CLSM/GROUT MIXES FOR HIGH-LEVEL WASTE TANK CLOSURES STRATEGIC RESEARCH AND DEVELOPMENT -- FY99 REPORT (U)
}

\author{
Author \\ Christine A. Langton, \\ Westinghouse Savannah River Company \\ Savannah River Technology Center \\ Aiken, SC 29808 \\ And \\ N. Rajendran \\ Consultant \\ Marietta, GA 30067
}

Date: January 15, 2000

Westinghouse Savannah River Company Savannah River Site

Aiken, SC 29808

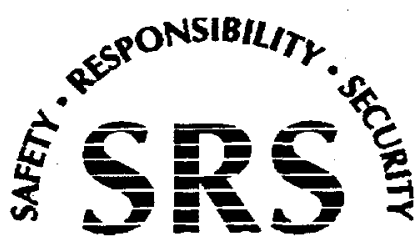


WSRC-RP-99-01014, Rev. 0

January 15,2000

Page i

REVIEWS and APPROVALS

Authors

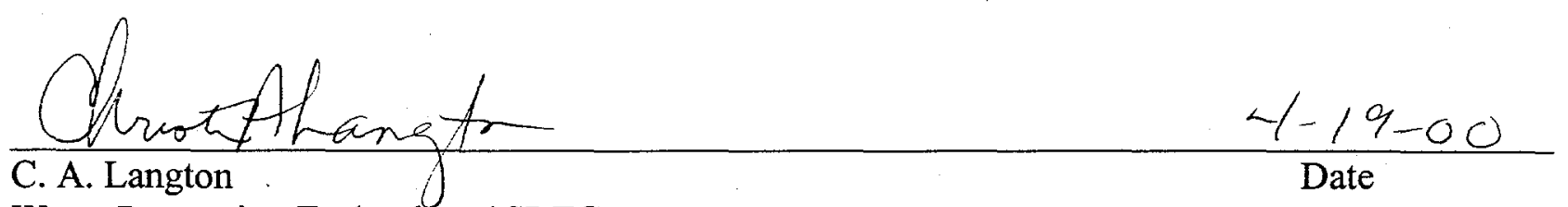

Waste Processing Technology/ SRTC

\begin{tabular}{ll} 
N.Rajendran & $4-19-00$ \\
\hline N. Rajendran & Date
\end{tabular}

Consultant

Approvals

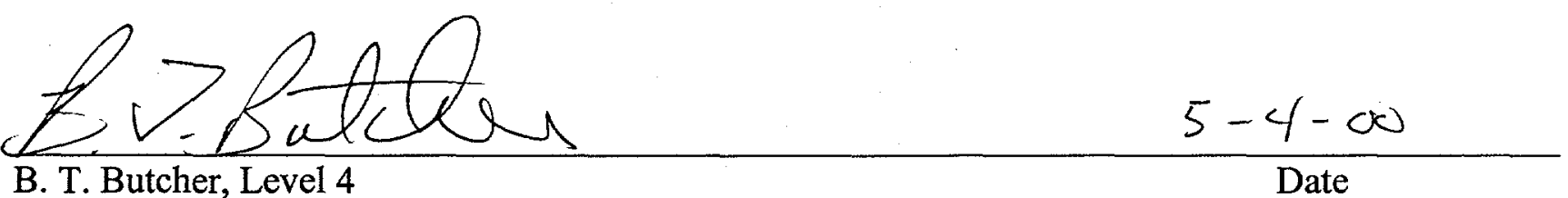

Waste Processing Technology/SRTC

LEttrem

W. E. Stevens, Level 3

Date

Waste Processing Technology/SRTC

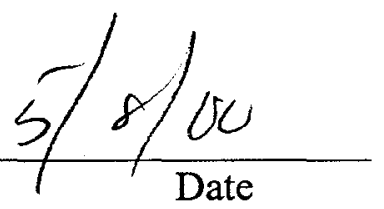

E. Saldivar, Level 4
High Level Waste Engineering

$6 / 28 / 00$

Date

Date 


\section{TABLE OF CONTENTS}

SUMMARY ...........................................................................................................................................

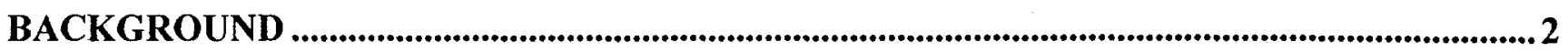

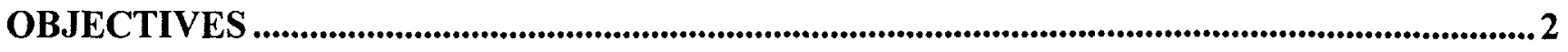

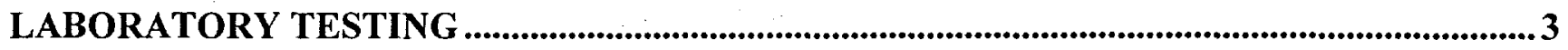

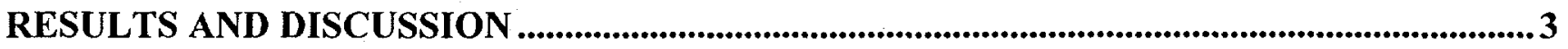

Zero-Bleed Soil CLSM and Reducing Soil CLSM......................................................................................

SRS Soil Dispersion Studies ............................................................................................................................ 4

Self-Leveling Zero Bleed Concrete....................................................................................................................5

Self-Leveling Zero Bleed Concrete - Other Applications.............................................................................5

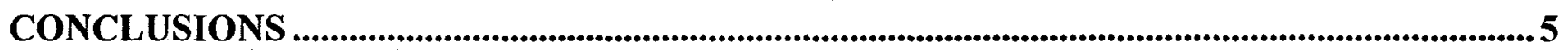

FUTURE WORK ................................................................................................................................... 7

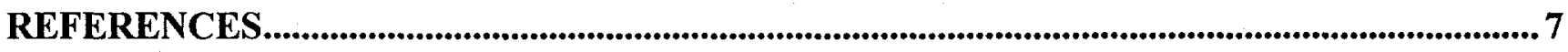

QUALITY ASSURANCE ................................................................................................................

ACKNOWLEDGEMENTS ............................................................................................................

\section{TABLES}

Table 1. Acceptance Criteria for Zero-Bleed CLSM/Grout and Common Fill. ...............................8

Table 2. Trial Mix designs for zero bleed soil CLSM............................................................................9

Table 3. Zero Bleed Soil CLSM Trial Mixes Test Results .................................................................... 10

Table 4. Trial Mix Designs Zero-Bleed Concrete....................................................................................11

Table 5. Zero Bleed Concrete Test Results....................................................................................................11

Table 6. Recommended Soil-Cement Mixes .......................................................................................... 12

Table 7. Recommended Zero-Bleed Concrete ............................................................................................ 12

\section{FIGURES}

Figure 1. Compressive Strength versus Cement Content of Aer0 Bleed Concrete Mixes .........13 
WSRC-RP-99-01014, Rev. 0

January 15,2000

Page 1 of 13

\title{
WESTINGHOUSE SAVANNAH RIVER COMPANY \\ SAVANNAH RIVER TECHNOLOGY CENTER
}

\author{
HIGH PERFORMANCE ZERO-BLEED CLSM/GROUT MIXES \\ FOR HIGH-LEVEL WASTE TANK CLOSURES \\ STRATEGIC RESEARCH AND DEVELOPMENT -- FY99 REPORT (U)
}

\author{
Christine A. Langton \\ Westinghouse Savannah River Company \\ Savannah River Technology Center, \\ Aiken, SC 29808 \\ and \\ N. Rajendran \\ Marietta, GA 30067
}

\section{SUMMARY}

The overall objective of this program, SRD-99-08, was to design and test suitable materials, which can be used to close high-level waste tanks at SRS. Fill materials can be designed to perform several functions including chemical stabilization and/or physical encapsulation of incidental waste so that the potential for transport of contaminants into the environment is reduced. Also they are needed to physically stabilize the void volume in the tanks to prevent/minimize future subsidence and inadvertent intrusion.

The intent of this work was to develop a zero-bleed soil CLSM (ZBS-CLSM) and a zero-bleed concrete mix (ZBC) which meet the unique placement and stabilization/encapsulation requirements for high-level waste tank closures. These mixes in addition to the zero-bleed CLSM mixes formulated for closure of Tanks $17-\mathrm{F}$ and $20-\mathrm{F}$ provide design engineers with a suite of options for specifying materials for future tank closures.

The ZBS-CLSM incorporates clayey sand soil from the SRS and has the potential to utilize suspect and low activity soil containing radioactive contaminants. In addition to filling HLW tanks and other contaminated tanks, the ZBS-CLSM may be useful for backfill in waste disposal trenches or vaults in the SRS E-Area, seepage basin closures, abandoned pipeline closures, reactor cooling water, disassembly basin closures, and disposal site capping.

The zero bleed concrete mixes were designed to be self-leveling and were intended to support the HLW Tank Closure program. The ZBC can be used as an intruder barrier in or outside of the HLW tanks. It can also be used to physically stabilize the riser plugs and structures associated with the tanks. Other potential applications include: concrete shielding (with the incorporation of heavy weight aggregate), concrete intended for underwater placement, and large slab construction. 


\section{BACKGROUND}

Over 150 high-level waste tanks require closure throughout the DOE complex. Approximately 50 of these are located at the SRS. Closure consists of emptying the tanks, encapsulating the incidental waste, and stabilizing the void space in the tanks to prevent future subsidence and intrusion. New and improved materials are required to accomplish these objectives and enable placement under difficult conditions. Improved materials will enable high-volume placements and waste encapsulation in addition to being cost effective. The new fill materials can also be used to close/stabilize underground pipelines and tanks in the commercial sector (nuclear, chemical, underground mining, and petroleum industries as well as the municipal services business).

As a result of the FY97 effort to design materials for the SRS High-Level Waste Tank closure effort, a zero-bleed Controlled Low Strength Material (ZB-CLSM) and a zero-bleed $2000 \mathrm{psi}$ grout were formulated and used to close Tanks $17-\mathrm{F}$ and $20-\mathrm{F}^{1,2}$ As a result of the FY98 effort, an alternative cellular zero-bleed CLSM and several reducing CLSM mixes were developed and field tested. ${ }^{3}$ In addition, three and four component All-In-One mix systems were developed. These mixes provide a wider range of engineering properties and are lower cost alternatives compared to the materials used in the first two SRS tank closures.

In FY98 two invention disclosures were prepared (zero-bleed admixture system and zero-bleed CLSM). Currently, these two disclosures are being combined into one patent application. Two technical papers were presented on this work in FY98.

In addition, the zero-bleed CLSM mix used to close Tanks 17-F and 20-F was used to cap two cells in Z-Area Vault 1 during FY98. Other applications at SRS, such as physical stabilization of underground pipelines and small tanks/vessels, are currently under review by the Environmental Restoration and Solid Waste Departments.

Finally, this effort supports stabilization of underground tanks and pipelines in the private sector. Examples of potential applications include closure of abandoned oil and gas pipelines, closure of abandoned water and sewer lines, closure/stabilization of underground petroleum and chemical tanks.

\section{OBJECTIVES}

The objective of this report is to document the status of this SRD 99-08 for FY99. The formulations recommended as the result of this effort make up a suite of mixes, which have a range of engineering properties, provide unique features, and are potentially cost effective options for future tank closures.

One of the objectives was to design a self-leveling ZBS-CLSM, which contained clayey sand soil that could be pumped up to 2000 feet into the SRS HLW tanks and flow at least 45 feet without segregation inside of the tanks. This mix was intended for use as the bulk fill material in the tanks (about 6000 cubic yards per tank). The second objective was to provide an opportunity for waste minimization by utilizing contaminated soil or suspect soil in tank fill materials. 
WSRC-RP-99-01014, Rev. 0

January 15,2000

Page 3 of 13

The objective of designing self-leveling zero bleed concrete mixes was to demonstrate that the zero-bleed admixture system developed for grouts could be applied to concrete. The resulting self-leveling ZBC mixes have potential applications as bulk fill for decommissioning basins and building structures, intruder barriers for future tank closures, waste disposal vault construction, large slab construction, and in underwater concrete placements.

\section{LABORATORY TESTING}

Trial mixes were designed and tested at the on-site Raytheon concrete testing laboratory. The tests, test protocols, and acceptance criteria are listed in Table 1. Most of the mixes were made in a 0.5 cubic foot Hobart mixer. Selected mixes were also prepared in the Raytheon three cubic foot capacity drum mixer.

The zero-bleed admixture system used in these mixes was the Adva Flow-Kelco-Crete system identified in the FY97 studies. In addition, another dispersent, sodium meta phosphate was use to disperse the clay in the soil used in the ZBS-CLSM. The sand in the soil was substituted for most of the ASTM C-33 sand required in the CLSM. Additional ASTM C-33 concrete sand was used to break up the clumps of soil in the ZBS CLSM. Class F fly ash was used to increase the fines in some of the mix designs and Grade 100 slag was used in the reducing ZBS-CLSM mixes.

\section{RESULTS AND DISCUSSION}

\section{Zero-Bleed Soil CLSM and Reducing Soil CLSM}

Twenty nine ZBS-CLSM trial mixes (Mixes A-Z) were prepared and tested. Mix designs are shown in Table 2 and test results are presented in Table 3. Mixes A to L contained SRS soil, cement, sand, fly ash, and the Adva Flow-Kelco-Crete ZB admixture system. Flows (measured per ASTM D6103) ranged from 11 to 14.5 inches were achieved in these mixes without segregation or bleed water. However, the strengths of the mixes containing fly ash were consistently low. The effect of the soil on the compressive strengths of the ZB CLSM mixes was evaluated by varying the cement contents from 150 to 625 pounds per cubic yard. Increasing the cement content by more than 2.5 times resulted in little strength gain even after 28 days. Mix K contained $625 \mathrm{lbs} / \mathrm{cyd}$ of cement. After curing for 28 days, this mix had a compressive strength of $290 \mathrm{psi}$. Construction grout containing $625 \mathrm{lbs}$ of cement per cyd. has a strength of at least 2000 psi after 28 days. Because of the low strengths, mixes containing SRS soil and fly ash are only suitable for zero-bleed bulk fill (minimum strength requirement of 50 psi at 28 days). Mix $\mathrm{L}$ containing the Adva Flow-Kelco-Crete system is recommended for bulk fill in tank closures.

Mixes $M$ to S (including R1, R2, and S1) and U contained SRS soil, cement, sand, slag, and a dispersing agent (Adva Flow or sodium metaphosphate). Some of the mixes also contained a thickening reagent (Kelco-Crete). This series of mixes indicated that higher strengths were achieved when slag was incorporated in the mix designs. For example, Mix M contained $250 \mathrm{lbs}$ of cement and $200 \mathrm{lbs}$ of slag per cubic yard and reached a strength of $680 \mathrm{psi}$ after curing for 28 days. (For comparison, Mix K contained $625 \mathrm{lbs} / \mathrm{cyd}$ of cement and reached a strength of 290 after 28 days and Mix T contained $450 \mathrm{lbs}$ of cement and $200 \mathrm{lbs}$ of fly ash per cyd and reached a strength of only $160 \mathrm{psi}$ after 28 days.) 
WSRC-RP-99-01014, Rev. 0

January 15,2000

Page 4 of 13

All of these mixes displayed excellent flow. However, it was difficult to control and predict bleed water formation in mixes without the thickening agent. Some mixes without the KelcoCrete did not generated bleed water while others did. Consequently, Kelco-Crete is recommended as an ingredient in ZBS CLSM mixes.

Differences were observed in the interaction between the two types of dispersing agents and the soils that were used in the tests. Adva Flow increased the flow of the soil CLSM mixes but, the results were erratic. This is because the Adva Flow was not very effective in dispersing the soil particles. Often many lumps of soil were still present after mixing. The sodium metaphosphate was much more effective in dispersing the soil particles. Consequently the soil CLSM was more uniform and the flow was more consistent. Mixes R (sodium metaphosphate only) and S1 (sodium metaphosphate plus Kelcocrete) are recommended for bulk fill materials and chemically reducing fill/grout suitable for stabilizing incidental waste in the HLW tanks.

Mix V is recommended as a non slag (non reducing) ZB soil CLSM mix which contains only sodium metaphosphate to achieve the flow and dispersion properties. (Mixes $\mathrm{L}$ and $\mathrm{V}$ are identical in composition except for the admixtures used to achieve the zero bleed properties.)

Mixes $\mathrm{W}, \mathrm{X}$ and $\mathrm{Y}$ were formulated to test the effects of two alternative dispersants, Bridge 35 and sodium meta phosphate, in the reference ZB-CLSM. Acceptable flows were achieved by increasing the amount of water from 63 (reference ZB-CLSM) to 77 gallons per cubic yard. However, both of these materials resulted in mixes that segregated and had bleed water even when the Kelco-Crete thickner was incorporated in the formulation.

\section{SRS Soil Dispersion Studies}

The soil used in these tests was a clayey sand collected from the SRS Burma Road borrow pit. The clay content was $20 \pm 5 \mathrm{wt}$. \% of the dry soil. The air dried moisture content of the soil was $15 \mathrm{wt} . \%$. To simulate use of this soil under field batching conditions, the soil was not shredded or crushed prior to adding it to the mixer. Several attempts were made to breakup the lumps and disperse the soil prior to adding the cement. Both physical methods, i.e., agitation of the asreceived-soil in the mixer, and agitation of the wetted soil in the mixer were unsuccessful. Mixing the wetted soil with Adva Flow or Adva Flow plus Kelco-Crete produced unsatisfactory results because of the long mixing/soak time ( 20 plus minutes) required to obtain a homogeneous slurry. Another dispersant, sodium metaphosphate, was identified which was very effective in dispersing the clayey sand soil.

A mixing protocol was established based on dispersion of the soil with the sodium metaphosphate. This involved pre-mixing the sodium metaphosphate with a portion of the mixing water. The solution was then added to the soil in the mixer. The soil was soaked in the sodium metaphosphate solution for 3-5 minutes prior to agitation. This was followed by agitation for 1-3 minutes. The remaining ingredients were added in the following sequence: sand, fly ash and/or slag, then cement. The remaining mixing water and additional admixtures (if required) were added and mixed for another 3 minutes.

Mix designs for the ZBS-CLSM containing the Adva Flow Kelco-Crete system are shown in Table 2 (A-M). Test results are given in Table 3. Based on trial and error, the optimization of the Adva Flow to Kelco-Crete ratio was found to be different than the ratio used in the soil-free 
systems previously tested. In addition it was found to be very sensitive to the total amount of water and to the extent to which the soil particles were dispersed in the mix. Balancing these admixtures to achieve the desired properties requires optimization of the Adva Flow-Kelco-Crete admixture ratio for each soil type.

Mix designs for the ZBS-CLSM containing the sodium metaphosphate are shown in Table $2(\mathrm{~N}-$ $Z$ ). Test results are given in Table 3. The sodium metaphosphate was much more effective in dispersing the soil particles than was Adva Flow. Consequently, it was easier to optimize the water content so that the bleed water and the flow could be easily controlled. Mix R was selected as the recommended formulation based on the test results.

Mixes containing both the Adva Flow-Kelco-Crete system and the sodium meta phosphate were also tested and produced acceptable properties. However, they had no advantage over the mixes containing the individual systems.

\section{Self-Leveling Zero Bleed Concrete}

A series of experiments were conducted to develop a zero bleed concrete using MIX C4000-6-0$2-\mathrm{A}$, the 4000 psi concrete in the WSRC procurement specification (C-SPS-G-00085 Rev.3). The cement, sand, and coarse aggregate contents were the same as this reference mix. The AdvaFlow-Kelco-Crete admixture system was substituted for the standard concrete water reducers, and the water content of this mix was adjusted to achieve the self-leveling, zero-bleed properties. First, the proportion of Adva Flow to Kelco-Crete was varied to determine the optimum mixture for concrete. This was determined to be 120 fluid ounces of Adva Flow to 400 grams of KelcoCrete (Mixes ZBA-ZBC). Based on these results, a design mix was developed from a three point curve (Mixes ZBD, ZBE, and ZBF). All of these mixes had a slump (measured per ASTM C143) of greater than 9 inches, an air content of less than 2 volume $\%$, and had no bleed water. Mix ingredients and test results are shown in Tables 4 and 5, respectively. The three-point graph of the trial mixes is shown in Figure 1. Based on these results, a self-leveling, zero bleed 4000 psi concrete mix design was identified and shown in Table 7.

\section{Self-Leveling Zero Bleed Concrete - Other Applications}

Self-leveling zero bleed concrete has several other potential applications such as, underwater concrete placements where mix cohesion is essential, concrete vaults for waste disposal/storage, floor slabs where elimination of shrinkage cracks is desirable, and high density concrete where minimizing air content and segregation are important.

\section{CONCLUSIONS}

In FY 99 three new materials, ZB Soil CLSM, reducing ZB Soil CLSM, and self-leveling ZB concrete, were designed and tested for filling, capping and stabilizing the SRS Type IV High-Level Waste Tanks. The Type IV Tanks are empty 1.3 million-gallon carbon steel vessels without cooling coils, pump shafts, or other equipment and obstructions. Since the results of the laboratory testing and pilot-scale testing of unobstructed tanks were verified in the actual Tank 17- and 20-F closures, there is a good correlation between laboratory results, acceptance criteria and successful placement in Type IV tanks. 
The ZB soil CLSM meets the requirements listed in Table 1 for the bulk fill. The reducing ZB soil CLSM meets the requirements for the stabilizing residual or incidental waste and for the bulk fill. The self-leveling $\mathrm{ZB}$ concrete meets the requirements for the intruder barrier and 2000 psi capping material.

A summary of the mixes determined to meet the acceptance requirements for closing the SRS Type IV HLW Tanks is shown below. Additional mix development for future tank closures will not be required provided that the performance requirements can be met by the mixes listed below.

\begin{tabular}{|c|c|c|}
\hline $\mathrm{FY}$ & Type IV Tanks & Mix Identification \\
\hline 1999 & $\begin{array}{l}\text { ZB Soil CLSM } \\
\text { Bulk Fill }\end{array}$ & $\begin{array}{l}\mathrm{L}, \\
\mathrm{V} \\
\end{array}$ \\
\hline 1999 & $\begin{array}{l}\text { Reducing ZB Soil CLSM } \\
\text { Bulk Fill and/or } \\
\text { Waste Stabilization } \\
\end{array}$ & $\begin{array}{l}\mathrm{R}, \\
\mathrm{S} 1\end{array}$ \\
\hline 1999 & $\begin{array}{l}\text { Self-Leveling ZB } 4000 \mathrm{psi} \\
\text { Concrete }\end{array}$ & ZB Concrete \\
\hline 1998 & $\begin{array}{l}\text { All-In One Mix } \\
\text { Reducing CLSM/Grout } \\
\text { (4-component) }\end{array}$ & $\begin{array}{l}\text { RG3 field tested } \\
\text { RG1 to RG6 }\end{array}$ \\
\hline 1998 & $\begin{array}{l}\text { All-In-One Mix } \\
\text { Reducing CLSM/Grout } \\
\text { (3-component) }\end{array}$ & $\begin{array}{c}\text { RGM1, RGM2, RGM3, } \\
\text { RGM4, RGM5 } \\
\text { Mixes cover a range of compressive strengths }\end{array}$ \\
\hline 1998 & $\begin{array}{l}\text { All-In-One Mix } \\
\text { Reducing CLSM/Grout } \\
\text { Containing A-Area Coal Ash } \\
\text { Containing D-Area Coal Ash }\end{array}$ & $\begin{array}{l}\text { 1ZB-APA, } \\
\text { 2ZB-APA, } \\
\text { 3ZB-APA } \\
\text { RGD2 }\end{array}$ \\
\hline 1998 & $\begin{array}{l}\text { Bulk Fill } \\
\text { Cellular CLSM }\end{array}$ & MF2 \\
\hline 1997 & $\begin{array}{l}\text { Bulk Fill Used in Tanks 17-F } \\
\text { and } 20-\mathrm{F}\end{array}$ & HP-ZB CLSM \\
\hline 1997 & $\begin{array}{l}2000 \text { psi Zero-Bleed Grout } \\
\text { Used for the Intruder Barrier } \\
\text { to Cap Tanks } 17 \text { - and 20-F }\end{array}$ & ZB 2000psi Grout \\
\hline 1997 & $\begin{array}{l}\text { Bulk Fill } \\
\text { Cellular CLSM Containing } \\
\text { D-Area Ash } \\
\end{array}$ & RGAF3 \\
\hline 1997 & $\begin{array}{l}\text { Common Fill } \\
\text { CLSM Containing A-Area Ash } \\
\text { for common construction }\end{array}$ & 8APA \\
\hline
\end{tabular}


WSRC-RP-99-01014, Rev. 0

January 15,2000

Page 7 of 13

\section{FUTURE WORK}

The following activities are suggested as additional work to support closure of all types of HLW tanks at SRS. Although the mix designs are recommended for only the Type IV tanks at this time, the information is applicable to the overall tank closure program.

- Test reactive additive/aggregate zero-bleed CLSM for chemical stabilization of contaminants. These results will support stabilization of soluble contaminants in the tank. Conduct comparative leaching studies with and without additives.

- Develop a low permeability CLSM for use in the annulus space, as capping material and in risers/piping.

\section{REFERENCES}

$$
\text { TR }
$$

1. WSRC-RP-98-00271, C. A. Langton and N. Rajendran, Laboratory and Field Testing of High performance-Zero Bleed CLSM Mixes for Future Tank Closure Applications (U), March 30, 1998.

2. WSRC-RP-98 7 -272, N. Rajendran and C. A. Langton, High Performance CLSM Field Mixing and Pumping Test Results (U), May 14, 1997.

3. WSRC-TR-97-0102, T. B. Caldwell, Tank Closure Reducing Grout (U), April 15, 1997

4. WSRC Concrete Specification, C-SPS-G-00085, Rev. 3.

5. WSRC-RP-95-1026, Rev.0; C. Langton and N. Rajendran, Utilization of SRS Pond Ash in Controlled Low Strength Material (U), December 1995.

6. C. A. Langton, N. Rajendran, and S. E. Smith, "Use Of Pond Ash in CLSM," Concrete International Journal, v. 20, no.12, p. 58-62, Dec.1998.

\section{QUALITY ASSURANCE}

Testing was conducted in accordance with ASTM standard practices and SRS procedures. Results are recorded in Laboratory Notebook WSRC-NB-98-00185.

\section{ACKNOWLEDGEMENTS}

B. L. Mhyer from the on-site Raytheon Testing Laboratory conducted the trial mix sample preparation and testing. M. Hudson provided facilities for sample preparation and mix testing.

Dr. S. Wood and the SRTC Strategic Research and Development program provided funding for this program. 
WSRC-RP-99-01014, Rev. 0

January 15,2000

Page 8 of 13

Table 1. Acceptance Criteria for Zero-Bleed CLSM/Grout and Common Fill.

\begin{tabular}{|c|c|c|}
\hline PROPERTY & $\begin{array}{c}\text { ASTM } \\
\text { REFERENCE }\end{array}$ & $\begin{array}{c}\text { HLW TANK FILL } \\
\text { ACCEPTANCE CRITERIA }\end{array}$ \\
\hline Flow & D- 6103 & 10 inches (minimum) \\
\hline Bleed Water. & $\mathrm{C}-232$ & Zero vol. \% after $24 \mathrm{hr}$ \\
\hline Air Content & $\mathrm{C}-231$ & N/A \\
\hline Unit Weight & $\mathrm{C}-138$. & $80 \mathrm{lbs} / \mathrm{ft}^{3}$ (minimum) \\
\hline Set Time & $\mathrm{C}-403$ & 30 hours (max.) \\
\hline Compressive Strength & $\mathrm{C}-39$ & \\
\hline Reducing grout/CLSM 7 days & & $50 \mathrm{psi}$ (min.) \\
\hline 28 days & & 500 psi (min.) \\
\hline 56 days & & $500 \mathrm{psi}$ (min.) \\
\hline \multicolumn{3}{|l|}{$\begin{array}{l}\text { Cellular CLSM and } \\
\text { HP-ZB Coal Ash CLSM }\end{array}$} \\
\hline 7 days & & $20 \mathrm{psi}(\mathrm{min})$. \\
\hline 28 days & & $50 \mathrm{psi}(\min )$. \\
\hline 56 days & & $120 \mathrm{psi}$ (min.) \\
\hline 2000 psi grout & & $2000 \mathrm{psi}(\mathrm{min})$. \\
\hline Common fill & & 30 to $150 \mathrm{psi}$ \\
\hline ZB Concrete ( $4000 \mathrm{psi}) 28$ days & & $4000 \mathrm{psi}$ \\
\hline Slump 4000 psi concrete & $C-143$ & 9 inches (minimum) \\
\hline
\end{tabular}


WSRC-RP-99-01014, Rev. 0 January 15,2000

Page 9 of 13

Table 2. Trial Mix Designs for Zero Bleed Soil CLSM.

\begin{tabular}{|c|c|c|c|c|c|c|c|c|c|}
\hline $\begin{array}{c}\text { rial } \\
\text { ixes }\end{array}$ & $\begin{array}{c}\text { Cement } \\
\text { Type I } \\
\text { (lbs/cyd) }\end{array}$ & $\begin{array}{c}\text { Soil } \\
\text { (lbs/cyd) }\end{array}$ & $\begin{array}{c}\text { Sand } \\
\text { (lbs/cyd) }\end{array}$ & $\begin{array}{c}\text { Grade 100 } \\
\text { (lbs/cyd) }\end{array}$ & $\begin{array}{c}\text { Fly Ash } \\
\text { (lbs/cyd) }\end{array}$ & $\begin{array}{c}\text { Water } \\
\text { (gals/cyd) }\end{array}$ & $\begin{array}{c}\text { Kelco- } \\
\text { Crete } \\
\text { (g/cyd) }\end{array}$ & $\begin{array}{c}\text { Adva- } \\
\text { Flow } \\
\text { (oz/cyd }\end{array}$ & $\begin{array}{c}\text { NaMP } \\
\text { (lbs/cyd }\end{array}$ \\
\hline $\mathrm{A}$ & 150 & 2300 & - & - & 500 & 188.6 & 350 & 90 & - \\
\hline $\mathrm{B}$ & 150 & 1725 & 575 & - & 500 & 140.0 & 550 & 180 & - \\
\hline $\mathrm{C}$ & 150 & 1875 & 575 & - & 350 & 150.0 & 550 & 180 & - \\
\hline $\mathrm{D}$ & 150 & 1800 & 600 & - & 400 & 180.0 & 500 & 130 & - \\
\hline $\mathrm{E}$ & 175 & 1800 & 600 & - & 400 & 180.0 & 550 & 187 & - \\
\hline $\mathrm{F}$ & 200 & 1725 & 600 & - & 400 & 158.6 & 500 & 180 & - \\
\hline $\mathrm{G}$ & 250 & 1750 & 600 & - & 400 & 170.0 & 500 & 180 & - \\
\hline $\mathrm{H}$ & 225 & 1750 & 600 & - & 400 & 165.0 & 500 & 180 & - \\
\hline $\mathrm{I}$ & 150 & 1750 & 600 & - & 475 & 160.0 & 500 & 180 & - \\
\hline $\mathrm{J}$ & 300 & 1750 & 600 & - & 325 & 165.0 & 500 & 180 & - \\
\hline $\mathrm{K}$ & 625 & 1750 & 600 & - & 0 & 185.0 & 500 & 180 & - \\
\hline $\mathrm{L}$ & 450 & 1750 & 600 & - & 200 & 182.0 & 500 & 180 & - \\
\hline $\mathrm{M}$ & 450 & 1750 & 600 & 200 & - & 175.7 & 500 & 180 & \\
\hline $\mathrm{N}$ & 300 & 1750 & 600 & 350 & - & 202.8 & 500 & 180 & - \\
\hline $\mathrm{O}$ & 150 & 1750 & 600 & 500 & - & 164.6 & 500 & 180 & - \\
\hline $\mathrm{P}$ & 450 & 1750 & 600 & 200 & - & 144.3 & 500 & 180 & 1.75 \\
\hline $\mathrm{Q}$ & 450 & 1750 & 600 & 800 & - & 150.0 & 500 & 180 & 1.75 \\
\hline $\mathrm{R}$ & 450 & 1750 & 600 & 200 & - & 133.0 & 0 & 0 & 1.31 \\
\hline $\mathrm{R} 1$ & 450 & 1750 & 600 & 200 & - & 133.0 & - & - & 1.40 \\
\hline $\mathrm{R} 2$ & 450 & 1750 & 600 & 200 & - & 129.3 & 0 & 0 & 1.40 \\
\hline $\mathrm{S}$ & 450 & 1750 & 600 & 200 & - & 150.0 & 500 & 0 & 1.31 \\
\hline $\mathrm{S} 1$ & 450 & 1750 & 600 & 200 & - & 149.3 & 500 & 0 & 1.40 \\
\hline $\mathrm{T}$ & 450 & 1750 & 600 & - & 200 & 150.0 & 500 & 0 & 1.31 \\
\hline $\mathrm{U}$ & 450 & 1750 & 600 & 200 & - & 192.0 & 0 & 0 & 2.62 \\
\hline $\mathrm{V}$ & 450 & 1750 & 600 & - & 200 & 166.6 & 0 & 0 & 2.62 \\
\hline $\mathrm{W}$ & 150 & - & 2300 & - & 500 & 77.0 & 275 & $45 *$ & - \\
\hline $\mathrm{X}$ & 150 & - & 2300 & & 500 & 74.3 & 275 & - & 1.75 \\
\hline $\mathrm{Y}$ & 150 & - & 2300 & - & 500 & 70.0 & 550 & - & 1.75 \\
\hline $\mathrm{Z}$ & 150 & 2300 & - & - & 500 & 63.0 & 550 & $45 *$ & - \\
\hline & & & & & & & & \\
\hline
\end{tabular}

* Bridge 35 dispersant. 
WSRC-RP-99-01014, Rev. 0 January 15,2000

Page 10 of 13

Table 3. Zero Bleed Soil CLSM Trial Mixes Test Results

\begin{tabular}{|c|c|c|c|c|c|c|c|}
\hline & & Trial \\
Mixes & $\begin{array}{c}\text { Flow } \\
\text { (inches) }\end{array}$ & $\begin{array}{c}\text { Unit } \\
\text { Weight } \\
\text { (lbs/cft) }\end{array}$ & $\begin{array}{c}\text { Bleed } \\
\text { Water } \\
\text { (vol. \%) }\end{array}$ & \multicolumn{5}{|c|}{ 7-day } & 14-day & 28-day & 160-day \\
\hline A & 10.5 & - & 1.0 & + & + & + & + \\
\hline B & 11.5 & 102.0 & 0 & + & + & + & + \\
\hline C & 11.0 & 105.6 & 0 & + & + & + & + \\
\hline D & 12.7 & 103.0 & 0 & + & + & + & + \\
\hline E & 11.7 & 102.4 & 0 & + & + & + & + \\
\hline F & 11.5 & 107.0 & 0 & + & + & + & + \\
\hline G & 14.5 & 103.0 & 0 & + & + & + & + \\
\hline H & 12.2 & 105.7 & 0 & 20 & 30 & 40 & + \\
\hline I & 11.5 & 104.6 & 0 & 10 & 20 & 30 & + \\
\hline J & 12.37 & 105.8 & 0 & 30 & 50 & 70 & + \\
\hline K & 12.75 & 105.0 & 0 & 150 & 210 & 290 & + \\
\hline L & 12.5 & 103.1 & 0 & 90 & 130 & 180 & + \\
\hline M & 11.8 & 103.2 & 0 & 250 & 440 & 680 & + \\
\hline N & 11.5 & 103.9 & 0 & 160 & 290 & 420 & + \\
\hline O & 12.25 & 107.6 & 0 & 310 & 600 & 1020 & + \\
\hline P & 11.2 & 110.0 & 3.0 & 140 & 240 & 360 & + \\
\hline Q & 12.5 & 107.4 & 2.6 & 140 & 260 & 470 & + \\
\hline R & 15.0 & 111.4 & 0 & 290 & 410 & 810 & $1100^{* *}$ \\
\hline R1 & 13.0 & 112.9 & 2.0 & 170 & 320 & 630 & $1050^{* *}$ \\
\hline R2 & 10.0 & 113.7 & 2.0 & 250 & 460 & 710 & $1085^{* *}$ \\
\hline S & 13.7 & 109.2 & 3.6 & 170 & 270 & 480 & + \\
\hline S1 & 11.75 & 110.3 & 0 & 200 & 360 & 560 & $785^{* *}$ \\
\hline T & 13.2 & 109.1 & 1.0 & 70 & 110 & 160 & + \\
\hline U & 11.5 & 96.5 & 0 & + & + & + & + \\
\hline V & 11.5 & 90.5 & 0 & 70 & + & 180 & 460 \\
\hline W & 12.0 & 100.6 & 1.5 & 50 & + & 140 & 575 \\
\hline X & 11.0 & 122.6 & 2.0 & 30 & + & 80 & 435 \\
\hline Y & 11.5 & 103.8 & 2.0 & 20 & + & 65 & 410 \\
\hline Z & 12.0 & 102.1 & 2.5 & 10 & + & 45 & 250 \\
\hline
\end{tabular}

+ Test specimens were not made.

** Tested after 120 days. 
WSRC-RP-99-01014, Rev. 0 January 15,2000

Page 11 of 13

Table 4. Trial Mix Designs Zero-Bleed Concrete.

\begin{tabular}{|c|c|c|c|c|c|c|}
\hline $\begin{array}{c}\text { Trial } \\
\text { Mixes }\end{array}$ & $\begin{array}{c}\text { Cement } \\
\text { Type I } \\
\text { (lbs/cyd) }\end{array}$ & $\begin{array}{c}\text { Sand } \\
\text { (lbs/cyd) }\end{array}$ & $\begin{array}{c}\text { Coarse } \\
\text { Aggregate } \\
\text { (lbs/cyd) }\end{array}$ & $\begin{array}{c}\text { Water } \\
\text { (gals/cyd) }\end{array}$ & $\begin{array}{c}\text { Kelco-crete } \\
\text { (g/cyd) }\end{array}$ & $\begin{array}{c}\text { Adva- } \\
\text { flow } \\
\text { (oz/cyd) }\end{array}$ \\
\hline Ref Mix & 560 & 1089 & 1900 & 35.5 & $22^{*}$ & $5^{* *}$ \\
\hline ZBA & 560 & 1089 & 1900 & 43.6 & 500 & 180 \\
\hline ZBB & 560 & 1089 & 1900 & 40.0 & 300 & 100 \\
\hline ZBC & 560 & 1089 & 1900 & 41.5 & 400 & 100 \\
\hline ZBD & 560 & 1090 & 1900 & 40.0 & 400 & 120 \\
\hline ZBE & 710 & 1040 & 1900 & 45.7 & 400 & 120 \\
\hline ZBF & 440 & 1150 & 1900 & 40.7 & 400 & 120 \\
\hline
\end{tabular}

Ref. Mix $=4000$ psi construction concrete

* Daracem 19 (water reducing admixture, oz/cyd)

** Air Entraining Admixture (oz/cyd)

Table 5. Zero Bleed Concrete Test Results.

\begin{tabular}{|c|c|c|c|c|c|c|}
\hline $\begin{array}{c}\text { Trial } \\
\text { Mixes }\end{array}$ & $\begin{array}{c}\text { Slump } \\
\text { (inches) }\end{array}$ & $\begin{array}{c}\text { Unit } \\
\text { Weight } \\
\text { (lbs/cft) }\end{array}$ & $\begin{array}{c}\text { Air } \\
\text { Content } \\
\text { (vol. \%) }\end{array}$ & $\begin{array}{c}\text { Bleed } \\
\text { Water } \\
\text { (vol. \%) }\end{array}$ & \multicolumn{2}{|c|}{$\begin{array}{c}\text { 7-day } \\
\text { (psi) }\end{array}$} \\
\hline Ref Mix & 3.5 & 137 & 1.5 & 2 & 2452 & 5068 \\
\hline ZBA & 9.5 & 137.3 & $\#$ & 0 & 2300 & + \\
\hline ZBB & 9.0 & 139.3 & $\#$ & 0 & 2510 & + \\
\hline ZBC & 9.0 & 142.8 & 1.6 & 0 & 2350 & + \\
\hline ZBD & 9.0 & 131.4 & 1.5 & 0 & 1850 & 4080 \\
\hline ZBE & 9.25 & 131.4 & 1.5 & 0 & 3980 & 5080 \\
\hline ZBF & 9.25 & 139.2 & 2.0 & 0 & 1960 & 2410 \\
\hline
\end{tabular}

\# Not Performed

+ Test specimens were not made 
Table 6. Recommended Soil-Cement Mixes

\begin{tabular}{|c|c|c|c|c|c|c|c|c|c|}
\hline Mixes & $\begin{array}{c}\text { Cement } \\
\text { I/II } \\
\text { (lbs/cyd) }\end{array}$ & $\begin{array}{c}\text { Soil } \\
\text { (lbs/cyd) }\end{array}$ & $\begin{array}{c}\text { Sand } \\
\text { (lbs/cyd) }\end{array}$ & $\begin{array}{c}\text { Slag } \\
\text { Grade 100 } \\
\text { (lbs/cyd) }\end{array}$ & $\begin{array}{c}\text { Fly Ash } \\
\text { (lbs/cyd) }\end{array}$ & $\begin{array}{c}\text { Water } \\
\text { gal/cyd })\end{array}$ & $\begin{array}{c}\text { Kelco- } \\
\text { crete, } \\
\text { (g/cyd) }\end{array}$ & $\begin{array}{c}\text { Adva- } \\
\text { flow } \\
\text { (oz/cyd) }\end{array}$ & $\begin{array}{c}\text { NaMP } \\
\text { (lbs/cyd) }\end{array}$ \\
\hline $\mathrm{V}$ & 450 & 1750 & 600 & - & 200 & 166.6 & 0 & 0 & $2.80^{* * *}$ \\
\hline $\mathrm{L}$ & 450 & 1750 & 600 & - & 200 & 182 & 500 & 180 & 0 \\
\hline $\mathrm{R}$ & 450 & 1750 & 600 & 200 & - & 133.0 & 0 & 0 & $1.40^{* *}$ \\
\hline $\mathrm{S} 1$ & 450 & 1750 & 600 & 200 & - & 149.3 & 500 & 0 & 1.40 \\
\hline
\end{tabular}

** $\quad 0.075 \%$ of the soil weight(SSD)

$* * * \quad 0.15 \%$ of the soil weight(SSD)

Table 7. Recommended Zero-Bleed Concrete

\begin{tabular}{|c|c|c|c|c|c|c|c|c|c|}
\hline Mixes & $\begin{array}{c}\text { Cement } \\
\text { I/II } \\
\text { lbs/cyd }\end{array}$ & $\begin{array}{c}\text { Coarse } \\
\text { Aggregate } \\
\text { lbs/cyd }\end{array}$ & $\begin{array}{c}\text { Sand } \\
\text { lbs/cyd }\end{array}$ & $\begin{array}{c}\text { SlagGrade } \\
100 \\
\text { lbs/cyd }\end{array}$ & $\begin{array}{c}\text { Fly Ash } \\
\text { lbs/cyd }\end{array}$ & $\begin{array}{c}\text { Water } \\
\text { gals/cyd }\end{array}$ & $\begin{array}{c}\text { Kelco- } \\
\text { crete } \\
\text { gms/cyd }\end{array}$ & $\begin{array}{c}\text { Adva- } \\
\text { flow } \\
\text { oz/cyd }\end{array}$ & $\begin{array}{c}\text { NaMP } \\
\text { lbs/cyd }\end{array}$ \\
\hline $\begin{array}{c}\text { ZB } \\
\text { Concrete }\end{array}$ & 635 & 1900 & 1100 & - & - & 43.0 & 400 & 120 & - \\
\hline
\end{tabular}


WSRC-RP-99-01014, Rev. 0 January 15,2000

Page 13 of 13

Figure 1. Compressive strength versus cement content of zero bleed concrete mixes.

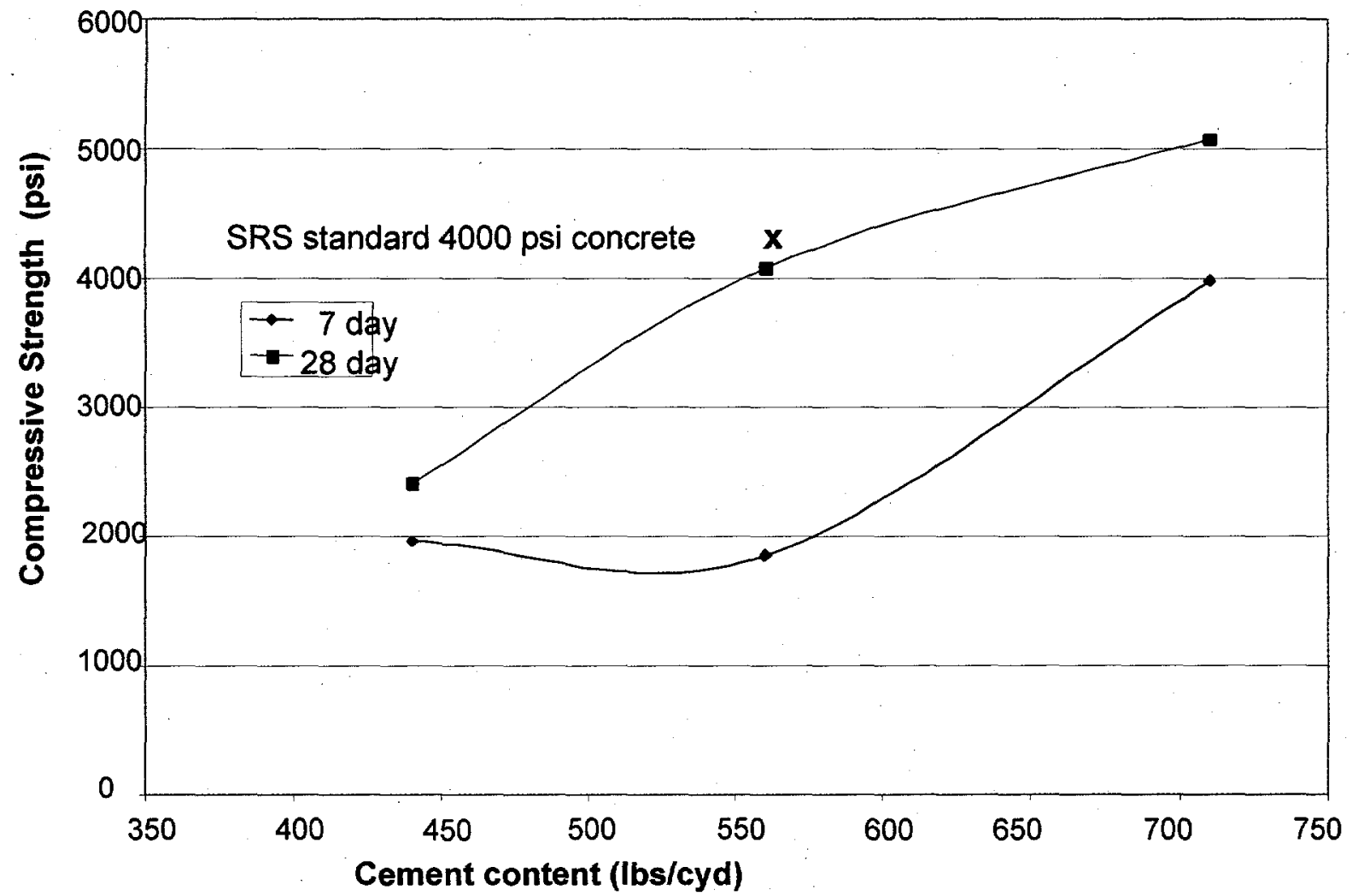

